\section{EERE-Supported International Activities in Latin America}

The Office of Energy Efficiency and Renewable Energy (EERE) is involved in a variety of international initiatives, partnerships, and events that promote greater understanding and use of renewable energy (RE) and energy efficiency (EE) worldwide.

In support of the Energy and Climate Partnership of the Americas (ECPA), EERE is working with several Latin American countries to advance EE and RE deployment for economic growth, energy security, poverty relief, and disaster recovery goals.

EERE's projects in the region are listed below:

\section{Argentina - Binational Energy Working Group}

During meetings in August 2009, U.S. government officials and counterparts from Argentina's Energy Secretariat agreed to explore the formation of a binational energy-working group to enhance joint collaboration on low-carbon energy activities. To that end, EERE is working to identify key opportunities for collaboration in the following priority areas defined by both countries: Climate Change Renewable Energy Impact Analysis, Energy Efficiency and Energy Service Company (ESCO) Market Development, Energy Efficiency Codes, Standards and Auditing, and Net Metering Regulatory Policy Analysis.

\section{Brazil - Binational Energy Working Group and Biofuels}

EERE will support initiatives that come out of newly reinvigorated bilateral energy dialogues. Partners for the biofuels cooperation include the Ministry of Foreign Relations,

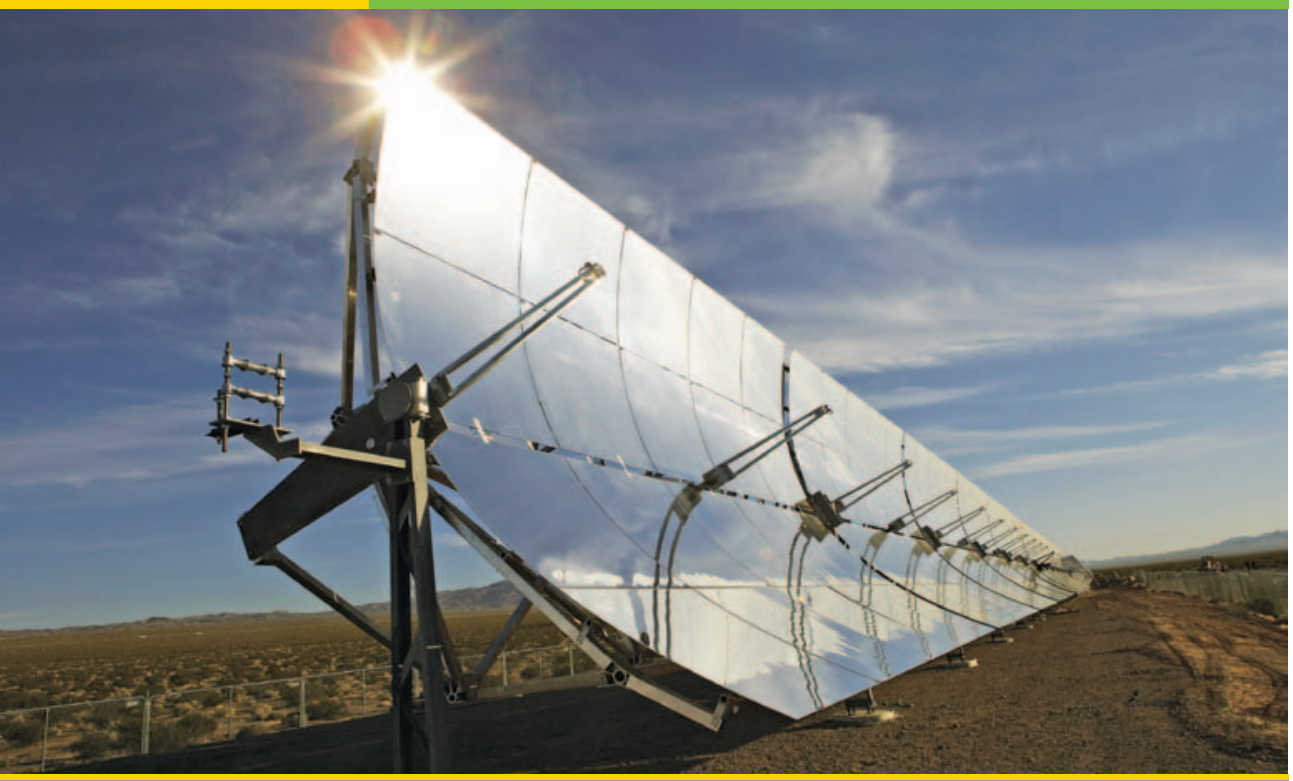

EERE is supporting countries such as Chile as the National Energy Commission works to foster development of concentrating solar power (CSP) projects.

Ministry of Science and Technology, Petrobras, and others. Other EERE initiatives in Brazil involve a techno-economic evaluation of advanced sugarcane refinery, a thermo-chemical production analysis, a life cycle assessment of biofuels to examine the sustainability of biofuels, direct/indirect land-use change, the benefits of integrated biorefineries (greenhouse gas reductions), and international conservation. EERE is also collaborating with partners in Brazil on advanced biofuel production R\&D methods, standards, and analysis tools. In the solar area, EERE is working with Brazilian scientists on silicon solar cell technology.

\section{Caribbean Region - RE Assessment and EE Training}

In support of several Caribbean governments and the Organization of American States (OAS), EERE will assist with local training initiatives and technical programs that show how to conduct energy efficiency audits and retrofits. EERE will also be involved with initiatives to strengthen communities' capacity to review and evaluate resource assessments related to indigenous renewable natural resources. This project will engage St. Lucia, Dominica, Grenada, St. Kitts and Nevis, The Bahamas, Antigua and Barbuda, and St. Vincent and the Grenadines. Partners include the CARICOM Secretariat, the Caribbean Electric Utilities Association (CARILEC), and the Renewable Energy and Energy Efficiency Partnership (REEEP).

\section{Chile - Renewable Energy Center and CSP Solicitation}

EERE is assisting Chile's National Energy Commission (CNE) as it establishes a new renewable energy center. The center will serve as a clearinghouse of information and analytic tools and leading source of expertise on renewable energy technologies for Chile and the region. EERE is also participating in relief efforts in the aftermath of the earthquake, and supporting CNE as it develops a solicitation for a $10 \mathrm{MW}$ concentrating solar power (CSP) project.

\section{Colombia - Pyrolysis Project}

EERE is providing assistance to Colombia with the development of a technoeconomic plan for pyrolysis of the agro-industrial residue biomass, which will 
help mitigate climate change in Colombia. Partners include the Oil Palm Research Center (CENIPALMA), Sugarcane Research Center (CENICAÑA), and Colombian Petroleum Institute (ECOPETROL-ICP).

\section{Costa Rica - Energy Efficiency Center}

The government of Costa Rica and the Natural Resources Defense Council (NRDC) are creating an Energy Efficiency Center in Costa Rica. EERE will provide technical assistance and help create training programs and training materials to run two initial energy efficiency auditor courses. Partners include the Costa Rica Electricity Institute (ICE) and the University of Costa Rica (UCR).

\section{Dominica - Small Wind}

EERE is assisting Dominica in assessing the viability of smaller, distributed wind generation as an alternative to traditional, megawatt-class, utility-scale turbines. Efforts will take into consideration available technologies, economics, and constructability to identify and model appropriate turbine technologies under 250 kilowatts. Partners include Dominica Electricity Services, Ltd (DOMLEC).

\section{Haiti - Reconstruction Efforts}

EERE is working with the Department of State and other U.S. agencies to provide green disaster relief in Haiti.

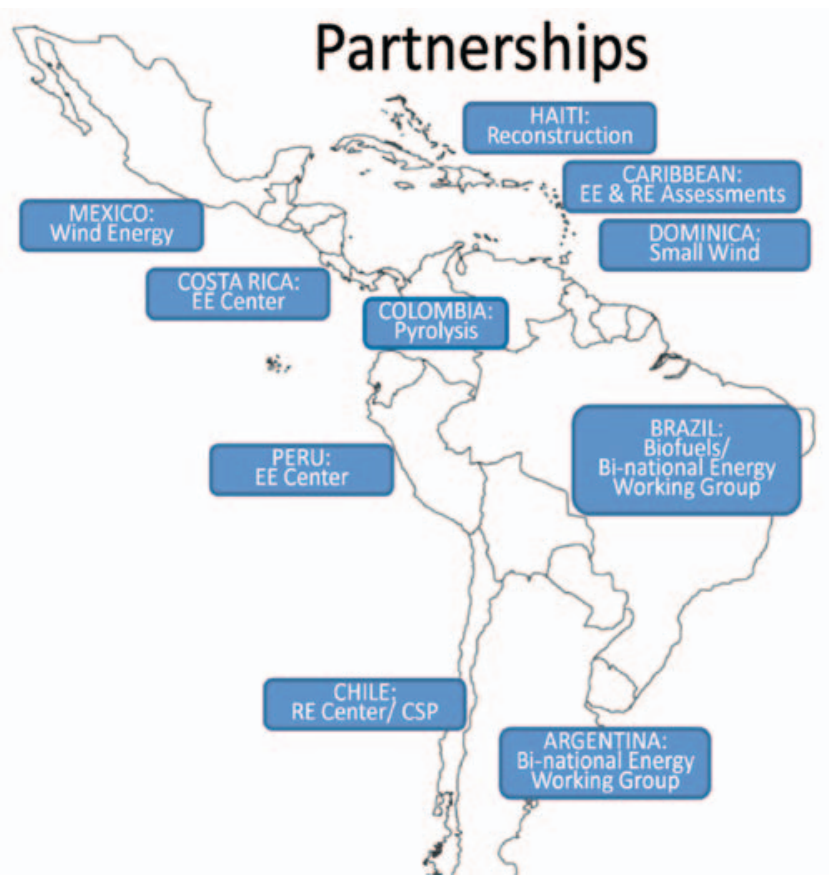

Mexico - Wind Energy

EERE and the Mexican government are collabo rating on a number of common-interest topics including wind resource assessment and mapping, and advanced wind technology development and testing. Partners include the Mexican Secretariat of Energy (SENER) and the Electrical Research Institute (IIE).

\section{Peru - Energy Efficiency Center}

At the "Americas Energy and Climate Symposium" in June of 2009, the U.S. Department of Energy and the Peruvian Ministry of Energy and Mines (MEM) announced the establishment of a Regional Energy Efficiency Center. Headquartered in Peru, the Energy Efficiency Center will support activities under the Energy and Climate Partnership of the Americas. EERE will work with the MEM to implement regional programs and projects to advance the development and deployment of energy efficiency initiatives.
We can strengthen the foundation of our prosperity and our security and our environment through a new partnership on energy. Our hemisphere is blessed with bountiful resources, and we are all endangered by climate change. Now we must come together to find new ways to produce and use energy so that we can create jobs and protect our planet. So today, I'm proposing the creation of a new Energy and Climate Partnership of the Americas that can forge progress to a more secure and sustainable future..."

President Barack Obama, Port of Spain, Trinidad, and Tobago, April 17, 2009, Summit of the Americas

Partnerships in our hemisphere hold the promise of opportunity, economic growth, and national security. Unleashing the potential of the Americas is imperative to achieving sustainable development and building capacity for innovation. This requires vastly enhanced cooperation on energy and climate change, which is a primary goal for the Energy and Climate Partnership of the Americas.

EERE is working to further existing ECPA initiatives and identify new ones. For more information about EERE's International Activities, contact:

Dan Birns

Adviser, International Activities Office of Energy Efficiency and Renewable Energy

U.S. Department of Energy 202-586-8767

daniel.birns@ee.doe.gov warer ENERGY

Energy Efficiency \&

Renewable Energy
EERE Information Center

1-877-EERE-INF (1-877-337-3463)

www.eere.energy.gov/informationcenter
Prepared by the National Renewable Energy Laboratory (NREL) NREL is a national laboratory of the U.S. Department of Energy Office of Energy Efficiency and Renewable Energy NREL is operated by the Alliance for Sustainable Energy, LLC 